\title{
Reviving the Labor Movement: A Comparative Perspective
}

\author{
Lowell Turner
}

\section{Introduction}

In recent years, the long-declining U.S. labor movement has refocused in new and promising ways on rank-and-file mobilization, in organizing drives, collective bargaining conflicts and political campaigns. Such efforts are widely viewed as the best hope for revitalizing the labor movement: breathing new life into tired old unions, winning organizing drives and raising membership levels, increasing political influence, pushing toward the power necessary to reform labor law and ineffective labor institutions. The stakes are high and the goals ambitious: to close the "representation gap" at the workplace, reverse growing economic and social inequality, and build new coalitions for expanded democratic participation in local, national and global politics.

The purpose of this paper is to gain perspective on American labor's current revitalization efforts by way of historical comparison to parallel developments in comparable large industrial democracies, in particular Britain and Germany, with a background look at Italy, France and Japan. In all democratic societies, labor movements contain elements that are service oriented and bureaucratic as well as elements that are more participatory and mobilization oriented. One or the other gains the upper hand at different times in history - thus periods of protest and mass demonstration are followed by quieter, usually longer periods of institutional consolidation.

The central argument examined in this paper is that periods of popular protest, including rank-and-file mobilization as well as broad coalition building, are necessary for the revitalization of labor movements. Revitalization means renewed influence (at the workplace and in politics), membership growth, and institutional consolidation (e.g. labor law reform). The alternative to revitalization is institutional decline and decay.

While the focus here is on labor, this is an argument that could also be generalized for institutions of democratic representation, from town-hall to parliamentary democracy. As such, the argument - and evidence - considered here contradicts the "too much democracy" views (e.g. Crozier, Huntington \& Watanuke, 1975) so influential throughout the social sciences. While that literature highlighted instability and ungovernability as outcomes of mass participation (in social movements, political party decision-making, etc.), the evidence here supports a deepening of democracy through expanded participation and indicates the revitalizing role of popular protest for democratic institutions. Focusing on the case of labor, this study at the same time builds broader arguments for testing across a range of democratic institutions. 


\section{Social Movements and Institutions}

Widespread mobilization, following this argument, is a primary force for institutional change, especially for institutions of democratic representation as in the industrial relations arena. The literature on social movements (from sociology and social history) and on institutions (from political science and industrial relations) are each useful in examining this relationship. Generally speaking, however, social movements are studied as dependent variables, to be explained, while institutions are looked upon as independent variables, shaping behavior. Here, considering the effects of mobilization and the causes of institutional change, the causal lines are reversed'.

In addition, new or reformed institutions of representation will themselves stagnate and decline over the long run, unless revitalized through popular protest and participation. Bob Dylan put it more poetically if not elegantly: "he not busy bein' born is busy dyin'."

Mobilization, of course, is not the only force revitalizing unions or shaping institutional change. But for institutions of democratic representation - in democratic politics and in industrial relations - social movements, collective action and popular protest are powerful ingredients for institution building as well as reform or transformation (Clemens, 1998). Just as firms are revitalized (or destroyed) by the competitive pressures of markets, so institutions of democratic representation are revitalized by popular participation and collective action.

At the same time, as implied in the social movement literature, institutional strength, or institutionalization, is itself a variable influencing mobilization ${ }^{i i}$. Strong institutions, as in Germany today, can reduce incentives for mobilization and institutional reform. Weak and declining institutions, as in the United States, can open the field for experimentation, innovation, and new mobilization-based strategies. Conflict within or across institutions or the breakdown of institutions, as in Italy in the 1990s, can open the door of political opportunity for new mobilization and reform. The causal lines between institutions and social movements thus run both ways, as specified above and as illustrated specifically in the case studies below.

\section{Labor and the Rise and Fall of Social Movements}

Social movements, periods of widespread mass mobilization, rise unexpectedly, and when they do, dispossessed groups and unheard voices may acquire new power and influence in the workplace, politics and society. But just as surely as they rise social movements also subside, usually within a few years - at least in part as a result of "counter-mobilization" by government, employers and other threatened interests (Kelly, 1998, pp. 83-107). Important, therefore, is the extent to which empowered activist leaders are able to reform or transform organizations and institutions, to solidify new rights and democratic procedures - institutions and rights that may well have to last until the next mass upsurge, often decades down the road.

Social movements are contagious, with spillover and crossover to other movements, operating in parallel and overlapping ways in "cycles of protest" that together target a variety of institutions (e.g. Tarrow, 1994). Thus labor movement renewal can be inspired or influenced directly by the spread of a broader social movement cycle iii. This is what happened in Britain and Germany (and in France, Italy and elsewhere) in the late 1960s and early 1970s, as labor movements were revitalized in broader currents of protest ${ }^{\mathrm{iv}}$. 
In the countries considered in this paper, however, especially in the U.S. and Britain but increasingly in Germany as well, unions today are in trouble, in need of renewal. At least in Britain and the U.S. labor also needs, and demands, significant reform in the institutions of industrial relations and their legal underpinnings. And in all three countries (most of all in the U.S.), important voices within the labor movement speak out for rank-and-file mobilization and a new type of social movement unionism to achieve these goals. Aimed at promoting active rank-and-file participation in collective bargaining, political campaigns and in drives to organize the unorganized, social movement unionism encourages worker mobilization within a local or national union, even in the absence of a broader, "organic" social movement. Proponents of social movement unionism, to be sure, would also very much like to instigate a broader social movement wave (Sweeney, 1996, pp. 121-157) - and it may well be that their success in promoting institutional change will depend upon the emergence of that wave.

Institutional reform, when it does occur, can be more or less successful and enduring, depending on politics, circumstances, and relations of power. Beyond unions and the industrial relations framework, employers and the state play central roles in shaping the prospects for workplace representation. British unions, for example, revitalized by the movements of the 1960s, promoted institutional reforms in the 1970s under a Labour government. Employers, however, were never well incorporated into the new arrangements, which in any case were piecemeal rather than comprehensive, leaving the new, weakly established institutions vulnerable to liquidation in state-led offensives of the 1980s. In this paper, nonetheless, the focus is on unions, their strategies and interactions with other social movements and the institutional framework in which they operate. While employer and government opposition often drive union decline (Goldfleld, 1987; Kochan, Katz \& McKersie, 1986; Towers, 1989), unions are neither passive objects nor helpless victims as often implied in the academic literature. The important question is why unions in the U.S. and U.K. were so vulnerable to government and employer challenges in the 1980s and 1990s, and what unions today can do to overcome such weakness.

The focus on union strategy and popular movements reflects a changing orientation in labor scholarship. For much of the 1950s, 1960s and 1970s, the American, Canadian and some European industrial relations models were widely viewed as constructive and reasonably well functioning sub-systems of a broader political economy (Kerr et al., 1960; Slichter, Healy \& Livernash, 1960). As a critique but also as an expansion of this perspective, the "corporatist" literature of the 1970s and 1980s analyzed the more or less central role of both labor and business in negotiating the terms of economic and political regulation (more so in some countries than others). In the 1980s, a new "transformation" (or strategic choice) literature analyzed union decline, especially in the U.S., along with employer opposition to unions, concession bargaining, and the rise of labor-management cooperation in a new context of intensified global competition (Kochan, Katz \& McKersie, 1986). The best hope for unions, in this view, was to change their ways, become more flexible, give up job-control unionism, enter into new partnerships with management (for mutual survival in changing world markets), and perhaps forget about a broader role in the political economy (of the European corporatist variety). By the mid-1990s, however, it was clear that such firm-level initiatives were proving all too few and all too insignificant in reversing union decline, especially in the U.S. 
In the face of American labor's failure to reverse decline - and in belated response to the collapse of the sub-system and the absence of a stable corporatist integration for labor activists and fed-up union leaders, led by John Sweeney, staged an electoral "revolution" and took power in 1995 at the AFL-CIO. The emphasis changed quickly from shoring up the subsystem and defending labor's position through concession bargaining and cooperation to a much more aggressive focus on rank-and-file organizing and mobilization. Much labor scholarship in the U.S. followed real world developments and shifted to studies of the successes and failures, the prospects and promise of labor movement revival (Bronfenbrenner et al., 1998; Fraser \& Freeman, 1997; Turner, Katz \& Hurd, 2001). Along with the Labour Party's rise to power in the U.K. in 1997, British labor scholarship moved in a similar direction (Heery, 1998; Kelly, 1998).

The new direction is perhaps understandable from a strategic choice perspective before the key choice had been employer opposition to unions, now it was renewed union organizing and member mobilization - although this choice is not necessarily what that literature advocated or would have predicted. The focus on expanded rank-and-file participation opened up a new activist and social movement orientation, for better or worse, with new leaders bringing new energy and vitality to a tired old movement. Key research questions shifted from "what is causing union decline" and "how much and under what conditions is the new cooperation spreading" to "what are the new union strategies," "under what conditions are they spreading," and "under what conditions do they succeed or fail?"

\section{The Global Context: Labor Under Pressure}

Contemporary union troubles in the U.S. and Europe began with prolonged economic crisis in the 1970s. Destabilization of the postwar settlements among government, business and labor resulted not only from oil crises and chronic inflation and stagnation, but also from the rising pressure of international competition. Japanese firms, to cite one important example, emerged on world markets with superior products at low cost, and in so doing threatened to roll back the auto, consumer electronics and other targeted industries in Western Europe and North America. States responded in various ways to the new threats, but no matter what the trade or economic policy, companies were forced to reorganize production. For many firms, this meant moving away from traditional mass production toward an uncertain, "lean" post-Fordist future and challenging entrenched worker attitudes and practices along with union rules and defenses (Boyer, 1988; Katz \& Sabel, 1985; Turner, 1991).

In the wake of economic crisis (1973-1983), unions in the U.S. and U.K. thus found themselves openly attacked by employers and governments, while unions in the rest of Europe struggled to find strategies appropriate for new production organization and economic policy. Results were predictable: unions everywhere on the defensive, less able to make gains in bargaining or membership, and in many cases accepting concessions instead of raising living standards and expanding workplace voice ${ }^{v}$.

By the 1990s, with faltering institutional supports, a new American and cross-European resurgence of worker-based collective action and protest seemed appropriate and necessary. Yet at precisely this time of great need, confronting intense new global and domestic challenges, labor movements found themselves all too demobilized (Touraine, 1986): in the U.S. 
and U.K. by decades of decline and business-as-usual unionism, in Germany, paradoxically, through a legacy of institutional success that had reduced incentives for rank-and-file organizing.

How did once powerful labor movements reach such difficult straits? And what could possibly be done to turn things around? With these questions in mind, the remainder of this paper examines cyclical patterns of long-term rise and fall for both social movements and labor institutions, and especially the interactions between mobilization and institutions, in Britain, Germany and the United States, with a background look at labor in Italy, France and Japan vi.

\section{The United Kingdom: From Devastation to Renewal}

The massive prolonged defeat of the British labor movement at the hands of Margaret Thatcher and her administration is one of the more dramatic turnarounds in the fortunes of a labor movement in the history of democratic society. With few exceptions, such sweeping nationwide routs of independent trade unionism have occurred only where democracy has been replaced by authoritarian governance: in Hitler's Germany, in Franco's Spain, in Pinochet's Chile. The British rout was not quite of that magnitude - unions and their leaders were not forcibly suppressed, and independent trade unionism did not disappear - but unions found themselves everywhere under attack in the labor market and in legal and political arenas, membership density plummeted from 56 to 30\% (1979-1997), and by the late 1980s, labor leaders were shell-shocked and once mighty British unions had become defensive organizations fighting for survival.

The British labor movement has a long tradition of voluntarism, an orientation that opposed state interference and allowed the power of shop floor mobilization to deliver the goods. British labor has also always been highly decentralized into hundreds of craft, industrial, mixed and general unions, in which the real power is often found in the person of the shop steward, at the shop floor or plant level. Products of Britain's early and gradual industrialization, both voluntarism and decentralization have been resistant to change, reflecting an ancient institutional framework deeply embedded in modern British history. As many have argued, the industrial relations framework is part of a larger set of economic and political institutions inherited from the age of empire, no longer appropriate to the economic demands of the 20th (let alone 21st) century and to a large extent responsible for Britain's long, painful decades of relative decline (Hall, 1986; Hobsbawm, 1969; Zysman, 1983).

As in the United States, the first legally consolidated unions in the U.K. were craft unions, beginning in the $1860 \mathrm{~s}$. A social movement dimension first entered the modern organized labor movement in the 1880 s and 1890 s, as industrial workers mobilized for recognition and against craft union exclusivity. These battles brought thousands of new workers into the labor movement and broadened, transformed, and greatly increased the power of the Trades Union Congress and its member unions (widespread mobilization thus shaping institutions). By 1907, the labor movement was ready to establish a second arm in the founding of the British Labour Party. From that time on, labor leaders looked at unions and party as two wings of the same movement, the one (the Labour Party) building the structures and membership of a modern political party and working its way toward national power, the other (the unions) together under one umbrella federation (TUC) but internally decentralized into 
thousands of voluntarist bases of power. Given such structure and tradition, this was never a cohesive labor movement, but it was one that was often capable of powerful influence in specific areas within the economy and in the political arena as well, as the Labour Party grew to displace the Liberal Party in Britain's essentially two-party system.

Although British unions experienced periods of mass mobilization - the General Strike of 1926 is one example - the power of such collective action was typically not used for the building of empowering institutions of industrial relations to protect labor in periods of economic downturn or political defeat. This pattern would reappear in the 1960s and 1970s.

In contrast to the U.S. experience, the British labor movement was broadly revitalized by the social movements of the 1960s. A powerful spirit of rebellion swept through the country in that decade, reflected in the music of the Beatles (and countless others) and taking organized form in the Campaign for Nuclear Disarmament, anti-Vietnam War movement, women's and environmental movements and more (including anti-Pinochet demonstrations in the 1970s). Unions participated in the antiwar movement while labor leaders confronted new demands for representation from within growing sectors of the economy - from the public sector, in service areas such as health care and teaching, and in service industries such as banking and insurance, with demands often arising from traditionally non-union white-collar technical, professional and managerial employees. Public sector and service industry unions grew rapidly, more than replacing any losses in traditional blue-collar manufacturing industries.

The growth phenomenon for British labor in the 1960s and 1970s was similar to public sector union growth in the United States in the same period - and no doubt related. Just as the music of rebellion quickly crossed national boundaries, so too did related social movements. These movements revitalized labor in the American public sector and throughout the British economy by way of young, radicalized employees, demanding a better workplace and not afraid to speak out, by way of the contagious effects of activism, as workers saw what others had achieved (be they workers in other areas, university students or peace demonstrators), and by creating a broad social fabric of mobilization, in which labor struggles could be sure to find new allies and supporters. One effect, in response to growing inflationary pressures, was a wave of wildcat strikes in the late 1960s and early 1970s - led in many cases by a new generation of union activists. The generational phenomenon is described in this way by John Kelly (1998, p. 99):

By the late 1960s, according to Phelps Brown, this new generation of union activists had become a "critical mass," sufficiently numerous and influential to force radical shifts in union policy and workers' militancy, albeit after long and often bitter factional struggles inside almost every one of Britain's largest unions.

Why was the labor movement revitalization effect so much broader in Britain than in America? For one thing, the public sector was much larger as a percentage of the workforce in the U.K. With so many industries nationalized and with Labour in power for much of the period (1964-1970, 1974-1979), there was little effective opposition to expanded union membership and activity in traditional and previously non-union sectors alike. For another thing, inflationary pressures, along with other chronic economic problems in the context of Britain's long "relative decline," became acute by the 1960s, giving workers good cause for militant demands aimed at 
maintaining or improving standards of living. In addition, Britain did not have the same domestic legacy of slavery that had divided the workforce into black and white, leaving white American labor leaders in many cases ambivalent about the civil rights movement (and it was civil rights that ignited all the rest in the U.S.). And finally, typically socialist British labor leaders had no use whatsoever, in most cases, for militant AFL-CIO anti-communism, the nearly terminal disease that isolated the American labor movement from the revitalizing forces of the 1960s.

In part as a result of social movement revitalization, British labor leaders found themselves with great power in this era. Under the Labour governments of Harold Wilson and James Callaghan, top TUC and member union leaders negotiated incomes policy agreements, in package deals that traded wage restraint for tax reductions and other labor-friendly policies (Leys, 1983; Taylor, 1980). In the 1970s, unions were incorporated into an explicit "social contract," with ongoing influence in government policy-making and in tripartite negotiations aimed at finding consensual solutions to economic problems. Labour governments passed union-friendly legislation - for tripartite wage councils, labor laws passed in 1974 and 1975 supporting union recognition and collective bargaining and establishing new rights in the workplace for workers and unions, 1976 legislation on statutory union recognition, and more all manifestations of institution building that moved beyond traditional voluntarism (Howell, 1995, pp. 163-171; Towers, 1997, pp. 165-170).

As a further reflection of their newfound power, British unions, it turned out, could also bring down what they had helped to build. In 1969-1970, incomes policies failed in part because many union leaders, and especially shop stewards out in the real centers of power along with the workers they represented, decided they were getting a raw deal: wage restraint in a period of rising inflation (thus real wage loss) with no meaningful compensation. With shop floor power, they pushed wages up in opposition to the national deals. A few years later, in 1974, under the Conservative government of Edward Heath, a successful miner's strike brought the government down and labour back to power. The on-again off-again success of new incomes policies from 1974 to 1979 again reflected both labor incorporation into policy-making and growing shop steward power to follow or to subvert. And finally, a series of strikes, especially in public services, in 1978-1979 (the "Winter of Discontent") contributed importantly to bringing down the Labour government and to the 1979 election victory of Margaret Thatcher and the Tories (Marsh, 1992, pp. 59-64).

Since 1979, the change in policy orientation of both Labour Party and trade unions has been dramatic. Nothing breeds an openness to innovation like failure after failure. Thatcher was re-elected in 1983 and 1987, and John Major was re-elected in 1992 and only defeated in 1997 , by which time Labour Party and unions had greatly moderated their politics and their image. For eighteen years, Tory governments pursued policies of radical anti-unionism, driving union membership downward along with union influence in the workplace and throughout society (Marsh, 1992; Towers, 1989) vii. The attacks were broad-based, sweeping and prolonged, including: macroeconomic policies of monetarism and fiscal austerity that deepened the recession of 1979-1983, collapsing employment in industries in which unions were strong and pushing unemployment rapidly upward (seriously weakening union bargaining power), specific policies of privatization and deregulation that attacked union influence in particular industries and firms, and legislative attacks in the form of a series of laws passed throughout the 1980s 
and into the 1990s aimed explicitly at curbing union power. Institutional reforms of the 1970s (such as wage councils and union recognition rights) collapsed with barely a trace. Unions did resist, especially in the early years, and occasionally won the modest victory. But overall the picture was one of massive defeat and decline, punctuated dramatically by the defeat of the once mighty National Union of Mineworkers in the winter of 1984-1985 (Towers, 1989).

Why was Britain's powerful labor movement so vulnerable in the 1980s? True, the attacks were intense and well-orchestrated and came in waves on multiple fronts. Any labor movement would have reeled under such attacks. But why was defeat in this case so thoroughgoing? Why was there no effective defense in virtually any of the areas of attack? An important part of the answer, I believe, lies in the fact that British unions, in their institutionally underdeveloped voluntarism, had inadequate institutional supports when economic and political circumstances turned against them. They did have legal rights regarding union recognition, first acquired in 1976 under a Labour government, but these were easily eliminated by the Thatcher government - made possible in turn by the centralization of political power in the British parliamentary system (Towers, 1989). Unions lacked a well developed framework for comprehensive collective bargaining, although multi-employer bargaining was widespread and bargaining coverage had reached $75 \%$ by 1979 . Nor did they have any European-style constitutionally mandated works councils or supervisory board participation or any other codetermination rights or even information rights on which to build, establish or protect influence in the workplace. The existing regulation of industrial relations in the workplace gave them little if any protection when, for example, an emboldened employer decided to ignore the union, or play one union off against the other, or co-opt workers into a house union friendly to the company and hostile to other unions. Weak institutionalization left British unions dependent upon their own ability to mobilize, upon their own organized power. When that power collapsed in the face of severe economic and political conditions, British unionists had no platform upon which to stand (see also Howell, 1995).

Although revitalized British unions had begun to build up useful institutions by the 1970s, they had also fought successfully against both Conservative and Labour government attempts to promote a more comprehensive package of industrial relations legislation (Batstone, 1988; Mcllroy \& Campbell, 1999). Operating still on the basis of voluntarist tradition, they sought to avoid legislated regulation that would constrain their efforts - even if such regulation would also have anchored them more securely at and beyond the workplace (Howell, 1995, pp. 171-175) ${ }^{\text {viii }}$. Their new, piece-by-piece, still weakly incorporated institutional framework could not survive and offered little support in the face of government opposition and employer withdrawal in the 1980s. And finally, internal union reform in the 1970 s played itself out not in strategic strengthening at multiple levels, but largely in broad decentralization, increasing the role of plant bargaining and the shop steward (Batstone, 1988). British unions did not adequately reform their own organizations for long-term influence in adverse circumstances (Howell, 1995).

By the time the Labour Party returned to power in 1997, the labor movement was a shadow of its previously vibrant self. Although exuberant on the surface about Labour's election victory, union leaders knew they would not get great support from a Tony B lair-led government, nor was there any chance of returning to the good old days. A new generation of labor leaders now pursued for the most part quite moderate strategies, which they sought to 
coordinate under the leadership of new TUC General Secretary John Monks (Waddington, 1995).

Aside from letting go of general militance and the specific advocacy of traditional socialist goals such as nationalization of industry, one big change involved a reorientation toward Europe. Long skeptical toward the market-oriented project of European integration, British union leaders went from anti-EC militance in the early 1980s to become the most proEuropean of British interest groups by the 1990s, by way of a 1987 "conversion" experience. Jacques Delors, President of the EC Commission, addressed the TUC convention that year, calling dramatically for a "social Europe," one that included strong unions and worker rights and social legislation, one that would give back to British unions some of the powers they had lost under Thatcher (so it was implied) while at the same time British unions would open a new front in the battle for a stronger social dimension - at home and in collaboration with their European counterparts. Weakened British unions accepted this offer of support and solidarity: based, it should be emphasized, on the institutionalized strength of other European labor movements and the early institutional arrangements and legislation they were building at the European level. While British unions had not used their earlier collective strength to build adequate institutional support, other European labor movements had - to the good fortune of British unions who now sought to draw on that institutional strength, as a new vehicle for reversing their decline (Heery, 1998, pp. 348-350; Howell, 1996, pp. 518-522).

From the European connection evolved a new stance on the part of some British labor leaders, one that would soon become prominent at the TUC: an orientation toward social partnership. A radical break with British labor's voluntarist past, this approach sought to rebuild strong" unions through good relationships with business leaders, via win-win bargaining, European works councils, and a new understanding of the realities of competition in the global economy. Elected TUC general secretary in 1994, John Monks, articulate and telegenic, embodied this perspective and put it forward on an ongoing basis in discussions with $\mathrm{CBI}$ (Confederation of British Industry) leaders, with heads of large corporations, and with government officials. The social partnership strategy aimed at nothing less than to: (1) bring Britain more fully into the European Union; (2) replace adversarial relations with cooperative relations that could raise both productivity and wages while giving employers less cause to oppose union recognition; and (3) improve the British economy while strengthening the unions.

Since Labour's election victory of 1997, the TUC has also worked closely with government ministries to develop and implement new legislation supporting the right of unions to organize, gain recognition and bargain. The White Paper "Fairness at Work," issued in early 1998, laid out the government's intention to set a positive new framework for good and just relations in the workplace. After pages singing the praises of entrepreneurship, the White Paper does indeed offer important rights to British unions. The two most significant are: (1) automatic recognition when the union has gathered a majority of signatures from the workforce (American unions call this "card-check recognition," and would give just about anything to gain that right); and (2) the right of union representation for any union member in any workplace, even for only one member (thus affording unions access just about anywhere for representation and organizing).

With "New Workplace" legislation now in place, British unions aim to build up the missing institutional framework, to make it possible for unions once again to consolidate and 
grow. Since social movement power in the 1960s and 1970s was not used to shape effective institutions, union leaders are now more quietly promoting institutional change, this time based to a large extent on the goodwill (and political debt) of their allies in the Labour government - in a fragile process that is limited and could still go awry. Addressing the need for internal reform, many unions have merged to form several "super unions," to consolidate political and economic strength from top to bottom.

It is unlikely, however, that new legislation, mergers and social partnership efforts will be enough to revitalize the British labor movement. For social partnership to work from a labor point of view, unions must be strong and capable if necessary of widespread rank-and-file mobilization (as the German case below demonstrates). And for the new legislation to mean anything, unions must use it actively to organize the unorganized. Increasingly, in fact, the voices of activism and new rank-and-file mobilization are heard within the TUC and its member unions. A central element of the TUC's "New Unionism," launched in 1996, is a commitment to organize new members, for "in-fill" (where a union already has a significant presence) but especially in new organizing, directed at non-union workplaces in service industries, electronics and other places where union presence is weak (Heery et al., 1998). To do this, the TUC has taken a close look at the new organizing orientation and efforts of the AFL-CIO and its member unions, as well as similar efforts in Australia. Delegations from the TUC have traveled to the States, while American organizing experts such as Andy Stern, SEIU president, and Richard Bensinger, founding director of the Organizing Institute, have come to the U.K. to work with TUC officials.

Such exchanges demonstrate a growing international solidarity - in this case mutual learning in cross-border union networks - as labor seeks global supports in a global economy (Heery, 1998, pp. 355-356). Such international exchanges have informed and reinforced the voices within the TUC and member unions calling for a new commitment to organizing. As an important first step, a TUC Organising Academy was founded in January of 1998, modeled explicitly after the AFL-CIO Organizing Institute. With backing from eighteen different unions, the Academy hired thirty-six trainees for its first year. Each union sponsored one or more trainees, who in the course of one year would get both classroom training and organizing placements with the sponsoring union. Applicants far exceeded the number of positions available, giving the Academy and unions the chance to screen candidates carefully. The majority of the new hires were women, and many came not from the labor movement but from other backgrounds in community organizing, environmental and peace movements and the like - the result of an explicit choice aimed at finding activist-minded organizers not already conditioned in traditional labor movement ways (Heery et al., 1998).

The Academy has generated considerable excitement at the TUC and some of the sponsoring unions. Critics point to the fact that two of the largest unions - TGWU and GMB have not participated, but in both cases those unions claim to be pushing organizing activity from within their own organizations. The new commitment to organizing extends beyond the Organising Academy, promoted here and there throughout the British labor movement by organizing activists. This new phenomenon parallels developments in the U.S.: a potential upsurge of rank-and-file-oriented unionism, in the British case to make use of the new legislation and to underpin high-level social partnership strivings and negotiations. That the advocates of social partnership and organizing are often quite opposed in their ideological and 
practical orientations (expressed at times in vociferous debate) does nothing to diminish the fact that for the revitalization of the British labor movement they may well be necessary complements (Heery, 1998, pp. 354-356; Heery et al, 2001).

\section{Germany: Strong Institutions, Rank-and-File Mobilization}

Strong unions, comprehensive collective bargaining and codetermination in contemporary Germany are products of a long history of collective action and popular protest. A strong labor movement dates from the late 19th century, works councils from the 1890s and from a revolutionary upsurge at the end of World War One, and both unions and works councils were strengthened in legislation passed in the 1970s, on the heels of the social movements of the 1960s. German unions have used periodic rank-and-file mobilization to increase bargaining power in negotiations with German employer associations and such top-down mobilizations have revitalized the unions throughout the postwar period. It is unlikely, however, that the mobilization of existing memberships will be enough to maintain numbers and influence in the face of today's intensified pressures (European integration, global economy, increasingly aggressive employers), as now even strong German unions find themselves in the unusual position of membership density decline. Yet unions in unified Germany have yet to mobilize for new organizing, as unions in the U.S. and U.K. have done. Can it be that strong institutions block innovations in grass-roots organizing and other strategies for renewal?

Unlike labor movements in Britain and the United States, German labor has undergone periods of brutal repression in the course of industrialization and German economic and political development. In the wake of Prussian-led unification in 1870, industrialization pushed forward at a "catch-up" rate, far faster than comparable processes in earlier industrializing Britain and America. German social-democratic and labor movements developed quickly in the face of hostile employers, so much so that conservative Chancellor Bismarck outlawed both unions and Social Democratic Party from 1878 to 1890 (Grebing, 1985). Unrest continued, however, as repression largely failed, and when the lid came off in 1890 (a result of modest concessions toward greater parliamentary democracy), union growth shot upwards: from 350,000 in 1890 to 850,000 in 1900 to 2.4 million in 1914 (Berghahn \& Karsten, 1987, p. 143).

Activist pressure during this period not only multiplied union membership levels but also made the Social Democratic Party the largest in Germany, and gained bargaining concessions and the establishment of some early factory councils at the workplace, all in an overall context of employer and government hostility. Although German workers and unions were largely coopted into the war effort in 1914, unrest continued in the face of repressive military and employer policies, exploding at the war's end in the form of revolutionary workers' and soldiers' councils across Germany. Forcibly suppressed, revolutionary councils nonetheless provided impetus for the incorporation of mandated works councils in founding legislation of the Weimar Republic in 1920. Today's works councils in Germany, it is therefore fair to say, are to a large extent products of a period of revolutionary uprising.

The unstable and ultimately tragic fate of the Weimar Republic is well known: subverted throughout its brief history by authoritarian forces within, such as the still largely Prussian civil bureaucracy and military, democratic forces failed to coalesce around a unified leadership or, after 1929, around a set of policies to lift Germany out of depression. In this vacuum of 
leadership and policy, Hitler came to power in 1933 and, among other things, abolished unions and works councils in his first few months in office - this time far more forcibly than his predecessors had done in 1878-1890 (Grebing, 1985, pp. 131-141).

After the horrors of war and holocaust, West Germany, with allied guidance and support, finally pulled together the ingredients for stable democracy. One ingredient was a new structure of unitary unions, open to socialists, social democrats, Christian democrats and conservatives alike, sixteen non-competing industrial unions to divide up the private and public sectors of the economy, linked together in one common labor federation. In negotiations with their employer association counterparts, these unions would in time provide comprehensive collective bargaining coverage to most West German (and after 1990, all German) employees. Another ingredient, the works councils, appeared spontaneously in workplaces after the war, building on revolutionary and Weimar legacies, formally incorporated in legislation of 1952 and 1972. Together, comprehensive collective bargaining and codetermination (the dual system) have become the institutional pillars of strong German unionism and industrial relations in the postwar and post-Cold War periods (Katzenstein, 1987, pp. 125-167; Markovits, 1986).

What prevented institutional decay or defeat at the hands of a long-serving conservative government (Helmut Kohl's sixteen years in office far exceeded Margaret Thatcher's eleven)? German unions were revitalized in three significant ways. The first was institutional. After the disappointment of 1952 codetermination legislation that drew sharp lines between unions and works councils in an attempt to keep unions out of the workplace, unions adapted by running slates of candidates in works council elections and winning. By the 1960s, in a process that would only deepen, unions had largely taken over the works councils, in effect turning these legally protected bodies to their own purposes. In so doing, the unions established two mutually reinforcing institutional anchors for their bargaining agenda and influence: comprehensive collective bargaining at the industry level and codetermination at the firm level.

The second source of revitalization, especially important for the argument presented here, came with the social movements of the 1960s. The protest orientation of student and antiwar movements took hold in the workplace in strike waves (often wildcat) of 1969, 1971 and 1973. Speaking of the first wave:

Unrest spread at the shop-floor level, which finally exploded in a wave of spontaneous unofficial strikes in September 1969. Dissatisfaction in the factories was fanned by the left-wing student movement which had proliferated in the wake of the Grand Coalition, but must also be seen as part of the world-wide upsurge in youth protest against the Vietnam War accompanied by a neo-Marxist critique of the international capitalist system (Berghahn \& Karsten, 1987, p. 210).

In fact, labor and student movements fanned each other. The result in the unions was a leadership pushed to a more activist position, to more aggressive demands. As Berghahn and Karsten (1987, p. 211) put it: "The response of the union leaders to the incipient rank-and-file radicalism was a traditional one: they put themselves at the head of the movement in an attempt to channel it." In other words, they rode the wave - and it pushed them to incorporate rank-and-file demands, to bring aboard new shopfloor leaders, and to push for stronger union and works council rights in the workplace. And such rights were soon legislated, in 1972 and 1976 codetermination revisions, by the Social-Democratic-led government (Thelen, 1992). The 
1972 legislation amended the Works Constitution Act and was especially important for strengthening ties between works councils and unions. 1976 legislation increased the numbers of labor representatives on the supervisory boards of large German firms.

The German labor movement was revitalized by the social movement energy of the 1960s in one additional way: by the 1970s, large numbers of student activists, socialist and proworking class in orientation, had gone to work for one German union or another, in a variety of different positions and capacities. By the 1990s, the "long march through the institutions" of many of these "68ers" (as they are known in Germany) had brought to positions of power and influence a cohort group oriented, through the experience of their formative years, toward social justice and rank-and-file mobilization.

The third key element of German labor revitalization has been periodic, large-scale mobilization. Although Germany in the postwar period is known for its low strike rate, German unions have nonetheless shown themselves capable of protracted strikes when necessary at high levels of solidarity and effectiveness (which is why they don't need to strike very often). Important, pattern-setting victories have come, for example, as a result of IG Metall strikes in 1984 (across West Germany; Thelen, 1992) and 1993 (across eastern Germany; Turner, 1998), and a widespread OTV public sector strike in 1992. Such strikes have not only mobilized the rank and file (renewing their commitment to the union and raising membership) but have "reunionized" the works councils, effectively forcing works councilors to lead the strike (wearing the union hat while leaving the works council hat at home) and thereby renew their own primary loyalty to union as opposed to firm.

Far more frequent than the actual strikes are the "warning strikes" that regularly accompany bargaining rounds used to demonstrate strike readiness and rank-and-file solidarity. On such occasions, workers walk out for an hour or a day, to show off their numbers and spirit, in a typically festive atmosphere in which employer idiocy or stubbornness are condemned while unionism and collective protest are celebrated. Union leaders are quite open in acknowledging that such displays of solidarity serve both to strengthen bargaining power vis-avis the employers and to renew rank-and-file ties to the union (e.g. Turner, 1998, pp. 1-16).

There is a social movement feel to these rank-and-file mobilizations, yet such expressions of popular protest are neither spontaneous nor grass-roots in origin, rather they are orchestrated from the top down for specific bargaining purposes. Given the long-term success of the German unions, in comparison to the unions of other large industrial societies, the tactic is arguably an effective one - and certainly a popular one with German workers. The question now, however, in an era of intensified European and global competition in which even German union membership is dropping, is: are such tactics enough? Are strong institutions and top-down rank-and-file mobilization enough to ward off decline?

The answer has to be negative. Even with strong institutions, even with the benefit of revitalization via the last social movement wave (the 1960s), even with the capacity to strike with solidarity and enthusiasm, union membership density is now on the decline (under $30 \%$ and falling). Unions have remained influential in German society for all of the above reasons, and especially thanks to their strong institutional position (Thelen, 1992; Turner, 1991). And they have received a boost, they still believe, in the 1998 election of a red-green federal government. Over time, however, declining numbers can only mean declining influence. 
The problem now is that while unions remain powerful in their strongholds, they are weak in their capacity to organize growing workforce groups such as white-collar, women and the young. For women and white-collar, some unions - such as OTV and HB V, now merged into "ver.di," a vast union of service workers - have done better than others. Young workers, however, present problems for all unions, and in all of these groups membership levels are low.

Yet German unions do not have developed strategies to organize the unorganized. They recognize the problem, discuss it widely, write articles and position papers, hold conferences. On a broad scale, however, they have not yet moved beyond existing approaches: exhorting shop stewards and works councillors to sign up the non-members in their workplaces and exploiting situations of collective bargaining conflict to bring in new members. Neither of these time-tested strategies, however, appear adequate to the current challenges: to push toward major breakthroughs in organizing women, youth and white-collar employees.

German union leaders know about the shift to organizing (much of it directed toward women and youth, as well as minorities) in the American and British labor movements. German unions have far greater resources at their disposal should they move in such a direction. Yet there is no indication that they are seriously considering such a move, even on a pilot project basis. Perhaps they are waiting to see results from Britain and the U.S. On the other hand, there are good reasons not to attempt so radical a shift in strategy: the expense is great and funds must be reallocated from somewhere else (and in the German case, that "somewhere else" may have strong institutional position of its own), union leaders set in their ways must be persuaded and re-educated, considerable internal conflict can ensue between organizing advocates and traditionalists, large numbers of new members (especially from new groups such as youth and women) with new demands can destabilize an organization and challenge existing leadership. It may be that German unions, in solid institutional position, are simply not desperate enough to move toward a risky and potentially de- stabilizing new strategy - even if that strategy may be necessary in the long run. It may take the desperate straits to which American and British labor movements have come to motivate such a major shift in strategy ${ }^{\text {ix }}$.

German unions are strong in part for the effect that social movements have had in building institutions: post-legalization upsurge of the 1890s built both strong unions and a powerful Social Democratic Party, revolutionary movements of 1918 generated (in defeat) the legislatively mandated works councils of the Weimar Republic in 1920, social movements of the 1960s and 1970s revitalized the unions internally and contributed to new legislation strengthening works councils and unions. German unions are also strong because they have continually renewed the union commitment of members and works councillors in warning-strike (and occasionally full strike) actions: rank-and-file mobilizations expressing an element of social movement unionism. As a result, German unions remain solidly positioned and well anchored institutionally within the German political economy - so well, in fact, that the urgent need for new strategies to organize the unorganized may go unmet. Against the potential turbulence that a shift toward fuller social movement unionism may bring, the institutional conservatism of the still powerful prevails. 


\section{The United States: From Business to Social Movement Unionism}

Over the past hundred years, the American labor movement has gone from craft-based, occupational unionism to transforming social movement (1930s) to social contract incorporation (1940s) to business unionism (1950s-1990s) to a major contemporary push toward renewed social movement unionism (e.g. Boyle, 1998; Brody, 1980; Fraser \& Freeman, 1997; Green, 1980) ${ }^{x}$. Labor upsurge in the 1930s helped build new institutions for collective bargaining and pushed union membership and influence upward (Gross, 1974, pp. 33-37). On the other hand, when labor missed the next social movement wave in the 1960s and 1970s, perhaps a tragedy of historic dimensions, American unions lost the opportunity for revitalization and fell under the weight of an escalating employer offensive into rapid decline and decay. Today's renewal efforts are bred both of desperation and the examples of a few organizing unions that did ride the 1960s wave and broke with business unionism in the 1970s and 1980s. Just as the popular upsurge of the 1930s helped to build and then breathe life into new worker rights and institutions, so the organizing activists of today aim to build the collective power necessary to reform, rebuild and revitalize labor's institutional supports for the challenges of the global economy.

The story of labor's social movement and institutional success in the 1930s is well known. In the face of economic depression and AFL craft exclusion, workers across the country, especially in mass production industries, demanded union representation. The National Labor Relations Act, passed by Congress in 1935 and upheld by the courts in 1937, gave recognition and collective bargaining rights where unions could gain majority workforce support. Organizers from $\mathrm{CIO}$ and AFL unions alike fanned out around the country, to take advantage of popular sentiment and readiness to mobilize. In a few years, union membership more than doubled. Rising working class protest gave political backing to the new labor laws and these same movements of protest then gave substance to the new laws and made the institutions work. Widespread mobilization, in this case and beyond a doubt, shaped institutions (Green, 1980; Gross, 1974) $)^{\mathrm{xi}}$.

Wartime solidarity incorporated the newly strengthened unions into the political economy through the War Labor Board, through informal access to President Roosevelt, through new influence in Congress and in other ways. Union leaders assumed the implied "social contract" would carry over into the postwar era - and it did, but in a more limited way. Labor's influence was restricted through Taft-Hartley legislation and in compromise strike settlements in which labor's power was confined to collective bargaining and shop floor enforcement at the expense of greater voice or codetermination in company decision-making (Brody, 1980; Gross, 1995). In the context of the new Cold War, many labor leaders consolidated control of their own organizations through a purge of the left (communist and non-communist activists alike) that eliminated internal opponents at the cost of stripping the labor movement of many of its activist-minded local, regional and even national leaders.

The capacity to promote renewed social movement unionism for the most part disappeared, replaced by what came to be known as business unionism: collective bargaining, enforcement of the contract, representational and other group services (health plans, insurance, group legal services) for the union member. While the new rights and services were valuable to the members, the life went out of the unions: people began to see them as service 
agencies and stopped going to meetings or otherwise participating - except for occasional mobilizations at contract time (which did show mobilization potential for those who might want to tap into it). By the time the AFL and ClO merged in 1955, although union membership density was near its peak (around 34\%), the stage was already set for the long-term dominance and eventual decay of a non-participatory business unionism. While economic restructuring and labor market changes, accelerating by the 1970s, made it essential for unions to organize new industries and groups of workers, a consolidated contract-oriented unionism had little capacity or interest in organizing new sectors of the economy.

What could have revitalized American unions for the increasingly difficult challenges of the 1970s and beyond? One answer: the civil rights, antiwar, women's and environmental movements (see, for example, Isaac et al., 1998). Institutions can be reinvigorated by social movements, or, in the politics of conflict, it is also possible for entrenched interests to beat back social movement influence - all too often to the detriment of the institutions.

Why did American labor miss the boat - the same boat, in a broad sense, that did revitalize the German, British, Italian and French labor movements? Above all, I would argue, it was the conservatism bred by established unionism, in which many union leaders presided over increasingly narrow, member-oriented organizations that had lost a broader vision and passion for social justice. This combined with ideologically intense Cold War anti-communism made many labor leaders (led by George Meany of the AFL-CIO) suspicious and at times quite hostile to new political stirrings on the left, from any of the movements of the 1960s.

There were important exceptions, and these show the lost potential. Martin Luther King was killed in Memphis in 1968 while supporting the union recognition strike of a thousand black sanitation workers against a white racist city council. The movie At the River I Stand shows in a beautiful way how the power of this labor protest was magnified by the power of the civil rights movement, and vice versa. The national union involved, AFSCME, used the strike victory in Memphis as a springboard for organizing other municipal employees across the South, and a cohort of AFSCME activists, empowered and radicalized by this experience, by the power they saw and felt in the convergence of these two popular movements, would go on to lead successful public sector organizing drives in the 1970s and 1980s, offering an alternative living model to the stagnation of business unionism.

The labor movement supported the passage of civil rights legislation, and particular unions such as AFSCME and UAW participated actively in the civil rights movement. But the exclusion of black and Hispanic workers from skilled jobs in the construction and other industries continued, as did the segmentation of jobs in the public sector and elsewhere - often with the collusion of unions whose first loyalty was to their existing (mostly white) members. Most labor leaders, in other words, gave their primary loyalty to the status quo, at a moment in history when a powerful social movement was transforming society, and could well have transformed and reinvigorated the labor movement as well (Isaac et al., 1998).

The story is similar for the women's movement, itself to some extent a product of the civil rights and antiwar movements. Outside the public sector, unions were little interested in organizing female occupational categories such as clerical workers and nurses ${ }^{\mathrm{xii}}$. There were again exceptions: in the public sector, in the growing interest of SEIU and other unions in organizing the health-care industry, in CWA's commitment to organizing telephone operators and new telecommunications occupations, in the growth of AFT and NEA, organizing teachers 
in the public schools. But the larger picture is the same: established labor leaders, threatened by the rise of women's liberation (as it was then called), showing little interest in bringing this potentially revitalizing force within the apparently stable house of labor.

For the anti-Vietnam War movement, the problems were political and generational. With a few exceptions (Walther Reuther of the UAW, for example, after 1968; Lichtenstein, 1995, pp. 420-438), top labor leaders, many of them survivors of the 1950s purges, were so deeply anti-communist they could not link up with this truly (and unruly) mass American movement. With its foreign policy funded by the State Department (part of the Cold War, redpurge deal), the AFL-CIO supported the war in Vietnam well after most Americans had come to see the war as a mistake. Media images of New York City construction workers beating up antiwar demonstrators reflected a broader feeling among top (and many lower down) labor leaders that the protesters were privileged, un-American college kids, anathema to labor's interests.

While labor leaders resisted, a vast swath of an entire generation was swept up in the antiwar movement - and many of these bright young activists came to see unions not as allies but as barriers to change. Far from discovering a source of reinvigoration in the swelling activism of American youth, labor leaders, stuck in George Meany-led anticommunism, lost credibility with much of an activist-minded, up-and-coming generation.

From this cross-movement hotbed in the 1960s and 1970s, a modern environmental movement also emerged (Shabecoff, 2000; Shutkin, 2000). Here too, the reaction of labor leaders was broadly negative. Far from working with environmental groups to find common interests, to develop, for example, a social-ecological reform strategy for the future of industry on a small planet (as German unions have done), labor leaders reacted to demands for environmental preservation in many cases solely as attacks on union jobs. Bumper stickers on the pickup trucks of construction workers chiding "Sierra Club take a hike!" reflected the visionfree brilliance of a politics of reaction. Once again, unions alienated a good part of an activist generation.

Social movements can revitalize institutions, and one way they do this is by sweeping away entrenched office holders. But such revitalization is a political process and can also be blocked by defensive, threatened leaders - in this case aided by the fact that the new social movements were not for the most part targeted at the workplace but rather at government policy. This allowed existing union leadership, from George Meany on down, to cordon off their organizations from the radical currents of change.

The main exception to this predominant pattern for the 1960s and 1970s lay in the public sector. Here, new enabling legislation (national, state and local) combined with the contagious activism of the era (an activism that mobilized blacks, Hispanics, women and youth) to produce something of a social movement unionism in many places (Isaac et al., 1998; Johnston, 1994). Here in a more benign environment, with less employer opposition (and often only after existing union leadership had been replaced), unions grew rapidly in the public sector throughout the 1970s, contrary to the opposite trend in the private sector. By the 1990s, union membership density in the public sector was more than triple that in the private sector. In the public sector, the movements of the 1960s in many cases did revitalize unions and the institutions of industrial relations - showing the potential had this happened on an economywide scale. 
In the long run, however, the activism of the 1960s may yet save the American labor movement. Many young rank-and-filers were strongly influenced by the movements of their formative years, and became a constituency inside their unions for change and for greater openness ${ }^{\text {xiii }}$. And many activists in the course of the 1970 s and 1980 s did find unions in which they could work and even thrive. John Sweeney, one could argue, leads the AFL-CIO today precisely because he was not threatened by the activists of the 1960s, and in fact began to hire them in the 1970s - knowing that these were people committed to social justice who would work hard for the cause. Such activists, at Sweeney's SEIU and at other unions such as AFSCME, ACTWU and CWA, would in the 1980s and 1990s play a major role in the organizing drives that laid the groundwork for a broad "changing to organize" campaign by the mid-1990s.

This is a common phenomenon in the rise and fall of social movements: when social movements subside (as they always do), they leave behind networks or communities of activists who defend the gains and carry on the campaigns, often at a grass-roots level (Staggenborg, 1998; Tarrow, 1994, p. 172). To carry on in this way was more difficult for American than European activists, since neither unions nor parties in the U.S. were particularly welcoming (Tarrow, 1994, pp. 176). American activists who did manage to move from the social movements of the

1960s into the labor movement for the long haul were either strongly committed, fortunate enough to link up with one of the few welcoming unions, or both.

It was not that established union leaders did not try to reverse decline. By the $1980 \mathrm{~s}$, it was no longer possible to pretend that things were fine. An employer offensive against unions had gathered force, starting on a large scale in the 1970s, receiving official blessing in Reagan's firing of the PATCO workers in 1981, driving union membership rapidly downward in the 1980s and 1990s. Decline was driven by employer opposition, backed by the state, but because labor at least in the private sector had missed the social movement boat, unions were more vulnerable to attack than they otherwise would have been. By the 1980s, they had neither strong, supportive institutions (as employers and government had whittled away at labor laws and their enforcement and interpretations, Gross, 1995) nor the force of widespread collective action $^{\text {xiv }}$. Labor leaders responded to the crisis in the areas they knew best - through concession bargaining and expanded services to members - and they moved beyond such modifications to experiment with labor-management cooperation. In all of these areas, modest gains were made in some cases, but nothing came close to turning the tide. Decline persisted (Kochan, Katz \& McKersie, 1986).

Labor refocused its efforts on keeping Democratic friends in Congress (the last barrier, perhaps, against union extinction), and getting a Democratic President elected as well. In 1978, with a Democratic Congress and President, unions had come close to getting some relief in modest labor law reform - only to be thwarted by a Republican filibuster in the Senate. With Democrats forever (it seemed) in control of the House, even with Reagan in power, union leaders had high hopes for a renewed push for labor law reform under the next Democratic Presidency. In addition to vigorous participation in state, local and Congressional campaigns, they campaigned hard for Mondale in 1984, Dukakis in 1988, and Bill Clinton in 1992.

In the meantime, a push to organize the unorganized did emerge within the labor movement, at the grass-roots level, led in many cases by activists of the 1960 s generation. Some unions began to shift resources toward organizing. For the most part, the unions that 
grew in the 1980s while others declined were the organizing unions. Within the councils of the $\mathrm{AFL}-\mathrm{ClO}$, in the face of failure in so many areas, the new voice began to be heard. In an effort to consolidate what had been learned and to train new organizers, the AFL-CIO founded an Organizing Institute in 1989, directed by Richard Bensinger (himself a veteran of the 1960s). As graduates of the Institute proved their worth in organizing drives, demand for their services rose and the Institute expanded. A new beachhead for organizing was carved out, and the dialogue and mutual learning grew among the Institute, organizing unions (such as SEIU, AFSCME, CWA, ACTWU, HERE, UAW), and other unions that wanted to organize.

Against this backdrop, when Bill Clinton and a Democratic House and Senate took office in early 1993, traditional labor leaders were elated. They had contributed to the Democratic victory and expected it to pay off (Friedman et al., 1994). Although they had no coherent strategy of their own for labor law reform, many had hopes for the Commission on the Future of Worker-Management Relations (the Dunlop Commission), appointed by Clinton to study and propose win-win reforms for labor-management relations and workplace regulation (Kochan, 1995). The Commission heard thousands of hours of testimony and studied long and hard, finally coming up with a consensual but watered down package - but not watered down enough to please either side. In the event, the ink was barely dry when the Gingrich revolution swept into Congress, foreclosing the possibility of any union-friendly legislative reform.

What was missing in 1994 was the same as in 1978: strong, popular pressure in favor of reforms aimed at reducing the barriers to union organizing success. The AFL-CIO and some member unions had organized letter-writing campaigns, but showed little inclination either to consult the members on this issue or to mobilize vast support (the support that a social movement unionism might have achieved) - and after decades of business unionism it is unlikely that rank-and-file support would have been there to mobilize.

Union organizing activists, meanwhile, carried on with their work. They had looked skeptically at the Dunlop Commission from the start, and now, bolstered by successes in the field and by the failure of just about every other approach, they began more openly to talk about in-house revolution and a massive shift of resources from servicing to organizing. When Newt knocked the final props out from under the aging "our Democratic friends will take care of us" gang - the labor equivalent in the political arena to business unionism in the economic arena - John Sweeney announced his candidacy for president of the AFL-CIO.

In his winning 1995 campaign, Sweeney and his slate partners, Linda Chavez-Thompson and Rich Trumka, rode the crest of a growing internal reform movement. Upon taking office, the new leaders swept house at the Federation, brought in younger activists and staff members (most AFL-CIO departments were soon headed by former 1960s activists), cleared movementdebilitating cold warriors out of the International Affairs Department, and announced a massive $\$ 20$ million shift of resources into organizing ${ }^{\mathrm{xV}}$. Since 1995, expanded training programs and hiring incentives for organizers, new union education programs, central labor council mobilizations, countless organizing drives, and highly effective grass-roots political campaigns have taken shape across the country. High-profile organizing, strike and political victories have raised labor's visibility and strengthened its role as a newly fortified actor in the political economy ${ }^{x v i}$.

This is a heartening story as far as it goes, and clearly offers the best (and perhaps last) hope for the revival of the American labor movement. Activists and leaders, however, have 
more in mind than a simple turnaround in union membership (which has yet to come ${ }^{\mathrm{xvii}}$ ). What many of them seek is nothing less than a widespread rank-and-file mobilization, one that can translate, at the appropriate time, into an even wider social movement coalition - in alliance with community groups, churches, environmental groups, women's groups, minority groups and others, fueled by inequality, by two decades of growing economic and social polarization in America (see, for example, Sweeney, 1996, pp. 154-157). They believe the conditions are right, and that indeed it will take the power of such a movement to transform the institutions, to reestablish, for example, the right to organize, to overcome the "representation gap" and the general powerlessness so widespread in the economy and society (Bronfenbrenner et al., 1998). And they also believe that in so doing, they will not only reduce America's extraordinary inequality but will push firms toward the high road, adding important "social value" at and beyond the workplace, in a manner compatible with strong economic performance (Wever, 1998).

In the American story, to summarize: social movements have in the past shaped democratic institutions of industrial relations. In the absence of renewed mobilization these institutions have stagnated and decayed and the current hope, and strategic orientation, of many American labor leaders and activists is for the organizing energy of a new social movement unionism to build the broad power necessary for institutional reform.

\section{Broadening the Comparative Analysis}

It is beyond the scope of this paper to examine in similar detail the labor movements of additional countries. To broaden the analysis and further examine the central arguments, however, labor-social movement interactions are sketched out below for three comparable large industrial societies.

Italy

In the 1950s and 1960s, Italian unions presented a rather dismal picture of divided and weakly institutionalized representation. The picture changed dramatically with the Hot Autumn strike and protest waves of 1969. In a context of rank-and-file upsurge, unions gained membership, contending federations (CGIL, CISL, UIL) collaborated, and a new institutional framework gave unions legitimacy in the workplace and beyond. Unions rode the power of the social movements of the 1960s, exploding in the workplace in 1969, to a new position of established influence in the 1970s - based on new works councils (RSU's) at the plant level as well as increasingly comprehensive collective bargaining with industry associations (Salvati, 1981).

By the 1980s, union influence was on the decline. A dramatic strike defeat at Fiat in 1980 and a national political defeat on wage indexation marked the change in union fortunes (Locke, 1995, pp. 108-110). Labor's "confederation of confederations" broke up in 1984 as contending federations went different ways in coping with the new crisis in membership and influence (Pellegrini, 1993). Social movement decline left the unions vulnerable to attacks from employers, government, alternative rank-and-file groupings (such as the COBAS), and each other. 
In the 1990s, the tide turned again. Even in relative weakness, Italians unions had retained both significant institutional position (at the workplace and in sector-based national bargaining) as well as a capacity for mobilization. When the postwar political power structure finally collapsed of its own corruption and in the face of popular protest, unions were one of the few organized forces with democratic legitimacy (Locke \& Baccaro, 1999). The federations once again worked closely together and stepped forward at the national level to play key roles in democratic reform and consolidation. From active support for the governing Olive Branch coalition to new national pacts with employers to consolidation at the plant level, Italian unions secured new positions of influence - rooted originally in the labor upsurge of 1969, consolidated in institutional reform, renewed in the 1990s on the basis of popular opposition to government corruption (Baccaro, Carrieri \& Damiano, 2001).

Most recently, the election of the conservative Berlusconi government in 2001 has put Italian unions on the defensive and in the political opposition - where they now play a leading role in mobilizations against anti-labor economic policy. In alliance with Olive Branch parties, unions appear to be in a strong position to play such a role. Italian unions offered a strong presence among the 100,000 demonstrators at the G-8 meetings in Genoa in July 2001 as well as at dozens of well attended follow-up demonstrations protesting the death of a young demonstrator and police actions under the Berlusconi government. If demonstrations against corporate globalization since 1999, in Seattle, Washington, DC, Prague, Nice, Quebec, Gothenburg and Genoa, are any indication, Italian unions may now be riding the crest of a new social movement wave.

\section{France}

One year before Italy's Hot Autumn, French workers and students virtually shut down the country in May and June of 1968 (Salvati, 1981). Triggered by masses of protesting university students, a general strike by French workers brought much of the economy to a standstill. As a result, French workers made enduring gains in wages, benefits and rights. For several years, contending federations (especially CGT, CFDT and LO) worked together for additional gains as well as for workplace and political influence. Major obstacles included the policies of a conservative-led French state, opposition from French employers, and continuing disunity among the unions. Hopes rose with the election in 1981 of socialist Francois Mitterrand as president of France, supported by most of French labor. Playing communists off against socialists, however, Mitterrand engineered a famous U-turn toward fiscal and monetary austerity in 1982-1983 that sharpened divisions among the unions. The decline of French unions deepened, and continued unabated from the late 1970s through the century's end (Daley, 1999).

While French unions and workers benefited from the social movements of the 1960s, new power and influence were not used to build a viable institutional framework, including consolidated union unity - in contrast to what occurred in Italy in the 1970s and again in the 1990s. By the time a socialist government reformed industrial relations in the early 1980s (the Auroux laws), unions were fighting among themselves and employers were able to make use of the reforms for their own purposes (Goetschy \& Jobert, 1993). The result for unions was longterm decline, with membership density dropping under $10 \%$ by the mid-1990s. 
In the continuing absence of union unity and strong institutions, French labor finds its remaining strength in state support and in often unexpected rank-and-file mobilization. As often followers as leaders in periodic strike mobilizations, French unions continue to be held at bay by both employers and government. While some unions experiment with U.S.-style organizing, a revitalization of the French labor movement continues to await unified efforts on the part of unions and leaders all too often at each other's throats (Daley, 1999).

Japan

Except for a ten-month period, the conservative LDP has governed Japan since 1955. One plausible explanation for the absence of viable political opposition lies in the weakness of independent unionism, traditionally a primary base for opposition politics in democratic societies. Major domestic efforts to strengthen unions were made during the American occupation following World War II, with independent unionism reaching over $50 \%$ membership density for the Japanese workforce (Cusumano, 1985, p. 138; Kuwahara, 1993, p. 224).

The story of the successful employer counterattack is well known. In the context of the Cold War, American occupying forces came to view many union leaders as too radical (especially those who were socialist or communist). Once American support was withdrawn, the independent unions could not stand up to widespread, coordinated attacks from large employers, in campaigns that replaced independent unions with today's famously cooperatively enterprise unions (Cusumano, 1985, p. 138; Halberstam, 1986, pp. 131-187).

Although unions play an important internal role at many large companies, national consolidation in the federation Rengo has not translated into a significantly independent political force (Shinoda, 1997). While unions rally in the annual "spring offensive" bargaining rounds, these rounds are largely coordinated by (and serve the purposes of) employers (Sako, 1997). The defeat of social-movement unionism in the 1950 s and 1960 s, rather than its consolidation into institutions of independent representation, may have helped Japanese export success but at the cost of long-term political stagnation in the absence of a viable democratic opposition.

With unions incorporated at the company level, the social movements of the 1960s remained student-based and focused on antiwar, anti-imperialist and environmental issues, except in the public sector. Here, independent and sometimes militant unions could be isolated and defeated, in a process that paralleled earlier private sector defeats.

In the Japanese case, the postwar rise of social-movement unionism did greatly strengthen an independent labor movement for a decade. The defeat of social-movement unionism, however, and its replacement with enterprise unionism, appears to have laid the groundwork both for lean production and for the post-bubble stagnation and paralysis since 1991, in a shaky democracy lacking solid political and economic opposition.

\section{Social Movements and Labor Institutions}

Social movements rise and fall, in unpredictable historical waves (made more predictable in one view as "long waves," Kelly, 1998, pp. 83-107). When the upsurge is led by or includes the labor movement, great pressure can be exerted on existing institutions of 
workplace representation for reform or transformation ${ }^{\text {xviii }}$. This occurred in Britain in the 1890s, Germany in 1918-1920, the United States in the 1930s, and Italy after 1969. In all of these cases, social movement power was used by labor to build new institutions, to further labor's interests in subsequent years well after the social movement had subsided.

The last international social movement wave occurred thirty years ago. Civil rights, antiwar, student, environmental and women's movement activism (to a greater or lesser degree in each country) spilled over into labor unrest, wildcat strikes and new workplace demands, and vice versa. In Britain and Germany - as in Italy and France - the labor movement was revitalized and strengthened by the upsurge of social movement activism. In Britain, unions grew rapidly and became more active in both economic and political arenas, but they did not use their new power to build effective, cohesive institutions. As a result they found themselves vulnerable when Thatcher came to power and economic circumstances turned against them. In Germany, unions rode the crest of wildcat strike waves, using the momentum of protest to push for improved codetermination rights, to strengthen the position of unions and works councils.

In the United States, by contrast, a "members-only" brand of unionism combined with ideological anti-communism to isolate much of the private sector labor movement from the social movements of the 1960 s. The opportunity for revitalization was largely blocked, leaving labor to face another two decades of decline. Enterprise unions in Japan held their incorporated position in the economy while also blocking the mobilizing effects of the 1960s, setting the stage for long-term decline for Japanese unions as well as for Japanese politics and economy. In Italy and France, unions were revitalized in the movement context of the 1960s: in Italy the new influence was consolidated through institution building and union unity, a consolidation that renewed itself in the 1990s following ups and downs in the 1980s; in France, revitalized unions squandered the social movement legacy through an inter-federation contention that still shows no signs of easing.

At the turn of the century, now twenty-five years from when the last social movement wave subsided, all these labor movements find themselves in need of renewal. In the U.S., the situation is downright desperate - and that desperation in a context of weak institutionalization has yielded significant efforts to experiment and innovate, with new strategies focused on rankand-file mobilization and coalition building. In the U.K., unions, shell-shocked after eighteen years of Toryism, are once again hopeful, with Labour in power and the European Union's social dimension ever closer. While advocates of social partnership take the high road toward Europe and labor-management collaboration, new American-style organizing activists take the low road of grassroots mobilization. Organizers share the American vision of social movement unionism, viewing rank-and-file mobilization as the necessary ingredient to activate institutional rights and bring new life to Britain's tired unions. German unions, by contrast, stayed strong through the 1980s and 1990s by way of entrenched institutions - and so far show little interest in pursuing the organizing strategies now building in the U.S. and U.K., in spite of declining membership. Revitalized Italian unions now face a conservative government, intent on pushing neo-liberal economic reforms that unions oppose, from their institutional bases and with whatever mobilization force they can produce. French unions continue to fight among themselves, even with some possible hope for the future in competitive organizing efforts. 
Japanese unions have shown little independent strength in promoting economic, political and social solutions to the prolonged stagnation of the past decade.

While rigorous proof is beyond the scope of this chapter, the evidence presented here offers support for the hypotheses introduced at the beginning:

Widespread mobilization is an important force for institutional change. While mobilization is no guarantee of success, the causal relationship applies broadly: in the U.S. in the 1930s, for example, and in the U.K., Germany and Italy in the 1960s-1970s. There is strong reason to believe, therefore, that organizing activists in various countries are on the right track in their efforts to mobilize workers, strengthen unions and reform labor institutions. At the same time, upsurge does not necessarily result in desired institutional change. In Japan in the 1950s and France in the 1960s, mobilization-driven reform efforts were defeated, in Japan by powerful employers, in France by union disunity.

New or reformed institutions of representation will themselves stagnate and decline over the long run, unless revitalized through popular protest and participation. We have seen this in the long postwar decline of American labor, in the 1980s in Italy and even more so in France, and in the slow decline of enterprise unionism across several decades in Japan. Although still strong, German labor may now face a parallel danger, if unions rest on their considerable institutional strength to avoid new mobilization.

Institutional strength, or institutionalization, presents opportunity structures that can facilitate or block mobilization. In the United States, declining institutions made room for widespread innovation, resulting in the rise of organizing and a new emphasis on rank-and-file mobilization. By contrast, German unions have maintained influence by virtue of strong institutions, a virtue that could turn into a liability if new mobilization is blocked.

Periods of widespread mobilization, we have seen, can reform institutions, especially institutions of democratic representation such as those shaping industrial relations. This has occurred time and again in the past, in different eras and countries. When the opportunity is seized by determined actors, the power of mass popular protest can revitalize, reform or transform institutions in ways that strengthen citizen, worker and union rights. As mass membership organizations, however, unions are particularly prone to decline, especially if institutional anchors are inadequate, in the long periods between collective action upsurge ${ }^{\text {xix }}$. The cure, argue today's American and British organizing activists, is a renewed social movement unionism that seeks to mobilize the rank and file - for its own sake in organizing drives, bargaining efforts and political campaigns, but also to help call forth the next broad social movement wave.

That popular mobilization shapes institutions is important precisely because of the powerful effect that institutions have, in the long periods between social movement waves, in shaping behavior. And behavior does tend to stay within institutional channels, at least until severe crisis or institutional decay sets in. Then institutions need renewal and the contribution of periods of popular unrest and mobilization is to sweep behavior out beyond the constraints of existing institutions, to make accelerated progress and reform possible. 


\section{Acknowledgements}

For helpful comments on an earlier draft, thanks to Sidney Tarrow, Steven Silvia, Ruth Milkman, Holly McCammon, John Kelly, Edmund Heery, Kerstin Hamann, Carola Frege, Martin Behrens and Mark Anner.

\section{References}

Baccaro, L., Carrieri, M, \& Damiano, C. (2001). Union strategies for revitalization in Italy. Paper presented at the International Seminar on Labour Movement Revitalization Strategies, International Labour Organisation, Geneva, April 19-21.

Batstone, E. (1988). The reform of workplace industrial relations: Theory, myth and evidence. Oxford: Clarendon Press.

Berghahn, V. R., \& Karsten, D. (1987). Industrial relations in West Germany. Oxford: Berg Publishing.

Boyer, R. (1988). The search for labour market flexibility: The European economies in transition. Oxford: Clarendon Press.

Boyle, K. (1998). Organized labor and American politics, 1894-1994: The labor-liberal alliance. Albany, SUNY Press.

Brody, D. (1980). Workers in industrial America: Essays on the twentieth-century struggle. New York: Oxford University Press.

Bronfenbrenner, K., Friedman, S., Hurd, R. W., Oswald, R. A., \& Seeber, R. L. (1998). Organizing to win: New research on union strategies. Ithaca: ILR Press/Cornell University Press.

Clemens, E. S. (1996). Organizational form as frame: Identity and political strategy in the American workplace, 1880-1920. In: McAdam et al. (Eds) (pp. 205-226).

Clemens, E. S. (1998). To move mountains: Collective action and the possibility of institutional change. In: Guigni et al. (Eds) (pp. 109-124).

Crozier, M., Huntington, S. P., \& Wattanuke, J. (1975). The crisis of democracy: Report on the governability of democracies to the trilateral commission. New York: NYU Press.

Cusumano, M. A. (1985). The Japanese automobile industry: Technology and management at Nissan and Toyota. Cambridge, MA: Council on East Asian Studies, Harvard University.

Daley, A. (1999). The hollowing out of French unions: Politics and industrial relations after 1981. In: Martin \& Ross (Eds) (pp. 167-216). 
Fraser, S., \& Freeman, J. B. (1997). Audacious democracy: Labor, intellectuals and the social reconstruction of America. Boston: Houghton Mifflin.

Friedman, S., Hurd, R. W., Oswald, R. A., \& Seeber, R. L. (1994). Restoring the promise of American labor law. Ithaca: ILR Press.

Goetschy, J., \& Jobert, A. (1993). Industrial relations in France. In: Bamber \& Lansbury (Eds) (pp. 149-174).

Goldfield, M. (1987). The decline of organized labor in the United States. Chicago: University of Chicago Press.

Grebing, H. (1985). History of the German labour movement. Leamington Spa: Berg.

Green, J. R. (1980). The world of the worker: Labor in twentieth-century America. New York: Hill and Wang.

Gross, J. A. (1974). The making of the National Labor Relations board. Albany: State University of New York Press.

Gross, J. A. (1995). Broken promise: The subversion of U.S. labor relations policy, 1947-1994. Philadelphia: Temple University Press.

Guigni, M. G., McAdam, D., \& Tilly, C. (1998). From contention to democracy. Lanham, MD: Rowman and Littlefield.

Halberstam, D. (1986). The reckoning. New York: William Morrow and Company.

Hall, P. A. (1986). Governing the economy: The politics of state intervention in Britain and France. New York: Oxford University Press.

Heberle, R. (1951). Social movements: An introduction to political sociology. New York: Appleton- Century-Crofts.

Heery, E. (1998). The relaunch of the trades union congress. British Journal of Industrial Relations, 36(3) (September), 339-360.

Heery, E., Delbridge, R., Simms, M., Salmon, J., Simpson, D., \& Stewart, P. (1998). It's not a recruitment drive, it's the rest of your life: New union organising in the United Kingdom. Paper presented at the UCLEA/AFL-CIO Education Conference on Organizing for Keeps: Building a 21 st Century Labor Movement. Lebaron Wyndham Hotel, San Jose, California, April 30-May 2. 
Heery, E., Kelly, J., \& Waddington, J. (2001). Union revitalization in Britain. Paper presented at the International Seminar on Labour Movement Revitalization, International Labour Organisation, Geneva, April 19-21.

Hobsbawm, E. (1969). Industry and Empire. Harmondsworth, U.K.: Penguin Books.

Houtzager, P. P., \& Kurtz, M. (1998). The institutional roots of popular mobilization: State transformation and rural politics in Brazil and Chile, 1960-1995. Ms., Department of Political Science, U.C. Berkeley.

Howell, C. (1995). Trade unions and the state: A critique of British industrial relations. Politics and Society, 23(2) (June), 149-183.

Howell, C. (1996). Women as the paradigmatic trade unionists? New work, new workers and new trade union strategies in conservative Britain. Economic and Industrial Democracy, 17, 511543.

Isaac, L., Christiansen, L., Miller, J., \& Nickel, T. (August, 1998). Intermovement relations: Civil rights movement spillover on labor militancy from Taft-Hartley to Reagan. Paper presented at the American Sociological Association meeting, San Francisco.

Johnston, P. (1994). Success while others fail: Social movement unionism and the public workplace. Ithaca: ILR Press.

Katz, H., \& Sabel, C. F. (1985). Industrial relations and industrial adjustment in the car industry. Industrial Relations, 24(3), 295-315.

Katzenstein, P. J. (1987). Policy and politics in West Germany: The growth of a semisovereign state. Philadelphia: Temple University Press.

Kelly, J. (1998). Rethinking industrial relations: Mobilization, collectivism and long waves. London: Routledge.

Kerr, C, Dunlop, J., Harbison, F, \& Myers, C. (1960). Industrialism and industrial man. Cambridge: Harvard University Press.

Kochan, T. A. (1995). Using the Dunlop report. Industrial Relations, 34(3) (July), 350-366.

Kochan, T. A., Katz, H. C, \& McKersie, R. B. (1986). The transformation of American industrial relations. New York: Basic Books.

Kuwahara, T. (1993). Industrial relations in Japan. In: Bamber \& Lansbury (Eds) (pp. 220-224). 
Leys, C. (1983). Politics in Britain. Toronto: University of Toronto Press. Lichtenstein, N. (1995). Walter Reuther: The most dangerous man in Detroit. Urbana: University of Illinois Press.

Locke, R. M. (1995). Remaking the Italian economy. Ithaca: Cornell University Press.

Locke, R. M., \& Baccaro, L. (1999). The resurgence of Italian Unions? In: Martin \& Ross (Eds) (pp. 217-268).

Markovits, A. S. (1986). The politics of the West German trade unions. Cambridge: Cambridge University Press.

Marsh, D. (1992). The new politics of British trade unionism: Union power and the Thatcher legacy. Ithaca: ILR Press.

McAdam, D. (1988). Freedom summer. New York: Oxford University Press.

McAdam, D., Tarrow, S., \& Tilly, C. (1999). Dynamics of contention. Manuscript, Center for Advanced Study in the Behavioral Sciences, Stanford, California.

Mcllroy, J., \& Campbell, A. (1999). Organising the militants: The liaison committee for the defense of trade unions, 1966-1979. British Journal of Industrial Relations, 37(1) (March), 1-31.

Pellegrini, C. (1993). Industrial relations in Italy. In: Bamber \& Lansbury (Eds) (pp. 126-148).

Sako, M. (1997). Shunto: The role of employer and union coordination at the industry and intersectoral levels. In: Sako \& Sato (Eds) (pp. 236-264).

Salvati, M. (1981). May 1968 and the hot autumn of 1969: The responses of two ruling classes. In: Berger (Ed.) (pp. 329-363).

Shabecoff, P. (2000). Earth rising: American environmentalism in the 21st century. Washington, DC: Island Press.

Shinoda, T. (1997). Rengo and policy participation: Japanese-style neo-corporatism? In: Sako \& Sato (Eds) (pp. 187-214).

Shutkin, W. (2000). The land that could be: Environmentalism and democracy in the 21st century. Cambridge: MIT Press.

Slichter, S. H., Healy, J. J., \& Livernash, E. R. (1960). The impact of collective bargaining on management. Washington, DC: Brookings Institution. 
Staggenborg, S. (1998). Social movement communities of protest: The emergence and maintenance of a local women's movement. Social Problems, 45(2), 180-204.

Sweeney, J. J. (1996). America needs a raise: Fighting for economic security and social justice. Boston: Houghton Mifflin.

Tarrow, S. (1994). Power in movement: Social movements, collective action and politics. Cambridge: Cambridge University Press.

Taylor, R. (1980). The fifth estate: Britain's unions in the modern world. London: Pan Books.

Thelen, K. A. (1992). Union of parts: Labor politics in postwar Germany. Ithaca: Cornell University Press.

Tilly, C, \& Tilly, C. (1998). Work under capitalism. Boulder: Westview Press.

Touraine, A. (1986). Unionism as a social movement. In: Lipset (Ed.) (pp. 151-173).

Towers, B. (1989). Running the gauntlet: British trade unions under Thatcher, 1979-1988. Industrial and Labor Relations Review, 42(2), 163-188.

Towers, B. (1997). The representation gap: Change and reform in the British and American workplace. New York: Oxford University Press.

Turner, L. (1991). Democracy at work: Changing world markets and the future of labor unions. Ithaca: Cornell University Press.

Turner, L. (1998). Fighting for partnership: Labor and politics in unified Germany. Ithaca: Cornell University Press.

Turner, L., \& Hurd, R. (2001). Building social movement unionism: The transformation of the American Labor movement. In: Turner, Katz \& Hurd (Eds) (pp. 9-26).

Turner, L., Katz, H., \& Hurd, R. (2001). Rekindling the movement: Labor's quest for 21st century relevance. Ithaca: ILR Press/Cornell University Press.

Voss, K. (1996). Collapse of a social movement: The interplay of mobilizing structures, framing, and political opportunities in the Knights of Labor. In: McAdam et al. (Eds) (pp. 227-258).

Voss, K., \& Sherman, R. (2000). Breaking the iron law of oligarchy: Union revitalization in the American Labor movement. American Journal of Sociology, 106(2) (September), 303-349.

Waddington, J. (1995). UK Unions: Searching for a new agenda. Transfer: European Review of Labor and Research, 1(1) (January), 31^3. 
Wever, K. (1998). International labor revitalization: Enlarging the playing field. Industrial Relations, 37(3) (July), 388-407.

\section{Zysman, J. (1983). Governments, markets and growth: Financial systems and the politics of industrial change. Ithaca: Cornell University Press.}

\footnotetext{
'The relationship is symbiotic: when political opportunity structures open up within the institutions, encouraging social movement upsurge, the lines of causation run from institutions to social movements (Houtzager \& Kurtz, 1998; Tarrow, 1994). This is a point of broad consensus in the social movement literature: that institutionalized political systems shape the prospects for social movements (McAdam, Tarrow \& Tilly, 1999, p. 3). On the other hand, there is also a growing sense that it is high time to move beyond explaining social movements to the study of social movement effects (Guigni, McAdam \& Tilly, 1998; McAdam, Tarrow \& Tilly, 1999) - one purpose of this paper.

ii Lest the hasty reader or sharp-eyed graduate student perceive an apparent tautology - institutions on both sides of the equation - the first argument has mobilization driving institutional change while the argument in this paragraph draws causal lines from institutionalization to mobilization. Thus in both cases, institutions and behavior are on opposite sides of the equation.

iii The term "labor movement" is confusing because it is widely used to refer to organized labor in general, even where bureaucratic unions have lost any movement spirit at all. Following conventional usage, the term is used here for organized labor in all of its forms from the more activist to the more bureaucratic. The different meanings of labor movement are clearly expressed in a widely used slogan in American union circles today: lets put the movement back in labor movement.

iv Voss and Sherman (2000) argue in fact that the presence of local activists with experience in other social movements a necessary ingredient for local labor movement revitalization.

${ }^{v}$ To be sure, other economic, political and social factors, beyond global competition and employer opposition, also undermined organized labor's position in modern economies. These included a shift from manufacturing to service employment, the rise of information technologies and industries, a shift toward part-time and other contingent work, and a new political predominance of economic policies of fiscal and monetary austerity.

${ }^{v i}$ The comparative analysis presented here is based on available literature and a series of parallel in-depth interviews with union leaders, from high levels to low, in the U.S., U.K. and Germany (1996-2000). Comparative historical analysis - of organized labor, social movements and institutional change - is the primary methodological approach. Observable patterns are compared analytically and cross-nationally, as evidence for hypothesis testing. Italian, French and Japanese background cases are based primarily on secondary literature.

vii John Kelly, in common social movement literature language, refers to this as counter-mobilization on the part of government and employers, in response to growing labor movement activism and power in the 1970s (Kelly, 1998, pp. 101-102, 129).

viii This is not to say that those packages were suitable from a union perspective. But the unions led the opposition to them without offering or negotiating an alternative package, one that would have given them a more unionfriendly, comprehensive institutional framework. See Clemens (1996) for an argument that institutional change is more likely when a particular institution is not embedded in an institutional framework. In the British case in the 1980 s, institutional change was facilitated in this way, and meant either elimination, serious weakening or transformation.

${ }^{\text {ix }}$ For Voss and Sherman (2000), a sense of crisis is a necessary ingredient in promoting major shifts toward local union organizing and tactical innovation. The other two ingredients are: support from national union headquarters (which in Germany may only come with perceived crisis), and local activists with experience in other social movements, who may bring tactical innovations (and there are no doubt many in Germany, the land of the Greens, who could contribute to union revitalization, should unions open the doors to organizers from other movements). ${ }^{x}$ An earlier version of this U.S. section appeared in Turner and Hurd (2001, pp. 12-21).

${ }^{x i}$ The relationship, to be sure, was interactive: once growing protest gave leverage to the Wagner forces to pass the new legislation in 1935, the NLRA, especially after clearing the Supreme Court in 1937, opened the door for
} 
more union organizing. Thus beneath the causal relationship social movements institutions lies a more complex picture: mass protest, new legislation, more mass protest and organizing, which in turn helped to consolidate the new institutional framework (see, for example, Green, 1980; Gross, 1974, pp. 33-37; Lichtenstein, 1995).

xii Karen Nussbaum, for example, former Director of the Working Womens Department at the AFL-CIO, told me in a research interview of her extraordinary frustration in the early 1970s in trying to get unions to support organizing drives of clerical workers.

xiii See Heberle (1951, pp. 118-127) on the concept of a political generation, shaped by the experiences of its formative years (ages 20-30), ready to rely on that learning later as the ruling generation (circa ages 40-65).

${ }^{\text {xiv }}$ Note the parallel here to an earlier era. Kim Voss (1996) argues that the 19th century Knights of Labor failed because of employer counter-mobilization, and because the KOL as an organization was unable to develop and implement appropriate new strategies to counter the employer offensive.

${ }^{x v}$ Thus veterans of earlier social movements help to promote new mobilization (or in this case awaken a slumbering labor movement to its movement potential), a pattern well known to social movement theorists (McAdam, 1988; Voss \& Sherman, 2000).

${ }_{\text {xvi }}$ Watershed victories, none of which would have been possible in the 1980 s, include a union election victory in 1999 for 74,000 homecare workers in Los Angeles, the result of a long, relentless SEIU organizing drive, a major strike victory at UPS in 1997, as the Teamsters campaigned on the broad issue of part-time work, with widespread public support and "fast-track" victories in Congress, in 1997 and 1999, led by the AFL-CIO in alliance with environmental groups, placing a major barrier in the way of trade agreements lacking Labor and environmental protections and laying the groundwork for the extraordinary "Battle in Seattle" of late 1999.

xvii In 1998, although union membership grew by 100,000, from 16.1 to 16.2 million, this growth rate still did not keep up with the pace of job creation as union membership density continued to drop (although at a very slow pace, from 14.1 to $13.9 \%)$. In 1999, however, union membership grew by 500,000, the largest growth in many years, allowing overall density to hold steady. But in 2000, in spite of expanded organizing effort and some notable victories, membership density dropped again, from 13.9 to 13.5\% (Bureau of Labor Statistics).

xviii See Heberle (1951, pp. 447^159) on social movements as a positive force that can, in pushing for reform, promote the interests of society as a whole. As an example, see Tilly and Tilly (1998, pp. 231-232) on the capacity of strike waves for changing institutions, including industrial relations, with positive effects on the changing organization of production.

${ }^{x i x}$ And in these periods of decline, the labor movement is commonly written off, even by the most sympathetic of scholars (Tilly \& Tilly, 1998, p. 231). See, for example, Touraine's (1986) epitaph for the labor movement, at least as a social movement. By contrast, see Kelly (1998, pp. 126-132) for an historically cyclical analysis that predicts the coming of a social movement period of labor upsurge and mass protest. 